\title{
Morphology and Anatomy of Leaf, Stem and Petiole of Luvunga crassifolia Tanaka (Rutaceae)
}

\author{
Sugathini Shunmugama, Nur Syamilah Roslia, Sugumaran Manickam ${ }^{b}$, Nur \\ Fatihah Mohd Yusoffa, Noorjahan Banu Alitheena, and Parameswari \\ Namasivayam ${ }^{a, *}$ \\ a Department of Cell and Molecular Biology, Faculty of Biotechnology and \\ Biomolecular Sciences, Universiti Putra Malaysia, 43400, UPM Serdang, Selangor, \\ Malaysia; b Institute of Biological Sciences, Faculty of Science, University of Malaya, \\ 50603, Kuala Lumpur, Malaysia.
}

Abstract Luvunga crassifolia is an underutilized plant in the Citrus family. Other than brief morphological descriptions, there are no published reports on other identification features of this plant. Thus, the current study was aimed to investigate macroscopic and microscopic diagnostic features of $L$. crassifolia leaves, stems, and petioles. Macroscopic characterization, optimization of histological procedure, and histochemical analyses of differential stains were carried out on the leaves, stems, and petioles of $L$. crassifolia. The histological method was optimized by modifying a few parameters including the number of fixation days, dehydration duration with degraded series of butanol, clearing and infiltration durations. Embedding and sectioning were performed on the tissues after infiltration. Histochemical analyses were carried out using differential stains to identify the cellular components in leaf, stem and, petiole tissue sections. This study showed that $L$. crassifolia leaves are amphistomatic. The compound leaves are trifoliate and arranged alternately. Pellucid dots were observed on both adaxial and abaxial leaf surfaces. Leaf cross-section consisted of schizogenous secretory cavities, whereas stem and petiole cross-sections show abundant schizolysigenous secretory cavities. Xylem, phloem, and pericyclic fibers were also found in the leaf, stem, and petiole sections. Calcium oxalates were present in the leaf and stem sections, while non-glandular trichomes were detected on stem and petiole sections. The information obtained from this study will be helpful for the identification and future taxonomicrelated studies of this plant species.

Keywords: Calcium oxalates, morphology, pellucid dots, secretory cavities.

\section{Introduction}

The Rutaceae family, commonly known as the Citrus family, is a large family of trees, shrubs, climbers, and rare herbs [1]. Rutaceae family, which originates from the order of Sapindales [2], is made up of approximately 160 genera and 1900 species, which can be found in tropical and temperate countries around the world [3]. Most forest types in Malaysia have representatives from the Rutaceae family. The flowers have four or five petals and sepals (occasionally three) that are not fused, sometimes three mostly separate and consist of eight to ten stamens [4]. The most notable characteristic of plants in this family is the presence of secretory cavities [3] and aromatic oils, which can be found in many species, especially from the members in the genus Citrus [4]. Plant anatomy is the study of internal structures, which can be observed using a light microscope. With anatomical studies, the arrangement of cells and tissues in a plant's ground, dermal, and vascular tissue system can be determined [5]. Leaf microscopic features, such as the shape of epidermal cells, type of stomata, and cell wall thickness, can be key 
elements for taxonomic identification. These aspects can also be useful to understand the phylogenetic relationships with other closely related taxa [6].

Luvunga crassifolia Tanaka [7] is an underutilized plant species where very little scientific information is known. The genus Luvunga falls under the subfamily Aurantioideae, subdivided into the Citreae tribe [8]. It is further classified under subtribe Triphasiinae which is the Minor Citroid Fruit Trees. L. crassifolia is one of the twelve species in the genus of Luvunga [9]. The species is naturally found in Peninsular Malaysia, Borneo, Singapore, and Sumatra [2] in lowland swampy forests and is categorized as a rare species [10]. This species is a climber with hooks. All the species under the Luvunga genus have recurved thorns/spines attached to the leaf axils, which aids them to cling to other forest trees [9]. According to Mabberley [11], species in this genus could be closely related to species in the genus Paramignya, based on their general appearances and morphological characterizations [4]. Until now, no records indicate that $L$. crassifolia has been sufficiently studied to understand its morphology and anatomy fully. Also, there are no published records of its macroscopic and microscopic features. Hence, this study is aimed to investigate the morphological and anatomical structures of $L$. crassifolia leaves, stems, and petioles which will provide useful information for species identification in the future.

\section{Materials and methods}

\section{Plant sample collection}

Plant samples of $L$. crassifolia were collected from the Rimba IImu Botanic Garden, University of Malaya. Herbarium voucher of this species (KLU 49658) was prepared and deposited in Kuala Lumpur herbarium (KLU) located in the Rimba IImu Botanical Garden, University of Malaya. Young leaves and stems were selected near the shoot apex of the plant and appeared to be in light green colour, whereas matured leaves and stems were selected in the middle or near the bottom of the plant and were dark green. Young and matured petioles were picked from the stalks of young and matured leaves, respectively.

\section{Morphological features of the leaves}

Morphological features of the leaves were observed and identified. The leaf architectures such as leaf venation, leaf arrangement, leaf organization, and petiole attachment were studied and tabulated [12]. Scientific photographs of the leaves and leaflets were taken using a Canon EOS 700 D DSLR camera.

\section{Preparation of leaf imprint}

Leaf imprints were prepared according to Grant \& Vatnick [13] to observe stomata and epidermal cells on the abaxial and adaxial surfaces.

\section{Stomatal density and stomatal index}

Stomatal density and stomatal index were calculated using a method and formula of Khandelwal [14]. Four leaves were collected and each leaf was divided into four sections. From each section, the number of stomata was counted in five different areas of the same radius $\left(r=4.049 \mathrm{~mm}, A=51.513 \mathrm{~mm}^{2}\right)$. Data of the leaf replicates were reported and statistically analyzed.

\section{Anatomy of leaf, petiole and stem sections}

Histological analyses were carried out using the paraffin embedding method according to Johansen [15], with a few modifications. Fresh plant materials including young and matured leaves, petiole, young stems, and matured stems were collected and used for anatomical studies. The leaflets were divided into basal, middle, and distal parts prior to fixation in FAA (formalin/acetic acid/50\% alcohol) for two days, while the stem samples were fixed in FAA for three days. Fixed leaflet samples were then passed through a graded series of tertiary butanol $(50 \%-100 \%(v / v))$ for one hour each step and were left in $100 \%(v / v)$ tertiary butanol overnight. Then, each clearing step was carried out for one hour, followed by infiltration for four days. For matured stem samples, minor modifications were performed as follows: three hours of dehydration with clearing for each step followed by nine days of infiltration. For young stem and petiole, two hours of dehydration and clearing for each step followed by six days of infiltration were carried out. The samples were then embedded in paraffin wax. Staining of leaf and stem sections were carried out according to Kraus et al. [16] using Astra Blue and Basic Fushcin. 


\section{Results}

\section{Leaf morphology}

L. crassifolia is a climber. Therefore, it has specialized hooks in a recurved spine shape. This feature helps the plant to grasp other structures to grow (Figure 1a \& 1b). The leaves are compound, trifoliate, and arranged in an alternate fashion on branches (Figure 1b). Each leaf consists of three leaflets (Figure 1c), which appears dark green on the adaxial surface and light green on the abaxial surface (Figure 1d $\& 1$ e). The pinnate venation is noticeable on both sides of the lamina. The shape of the lamina is obovate and symmetrical. Unlobed leaflets have smooth margins and swollen base petioles. The base is ovateshaped and the apex is either mucronate or emarginate in shape. The midvein is more raised on the adaxial surface compared to the abaxial surface. The length of the leaflets is $(13.9 \pm 0.667) \mathrm{cm}$ and the width of the leaflets is $(6.77 \pm 0.751) \mathrm{cm}$.
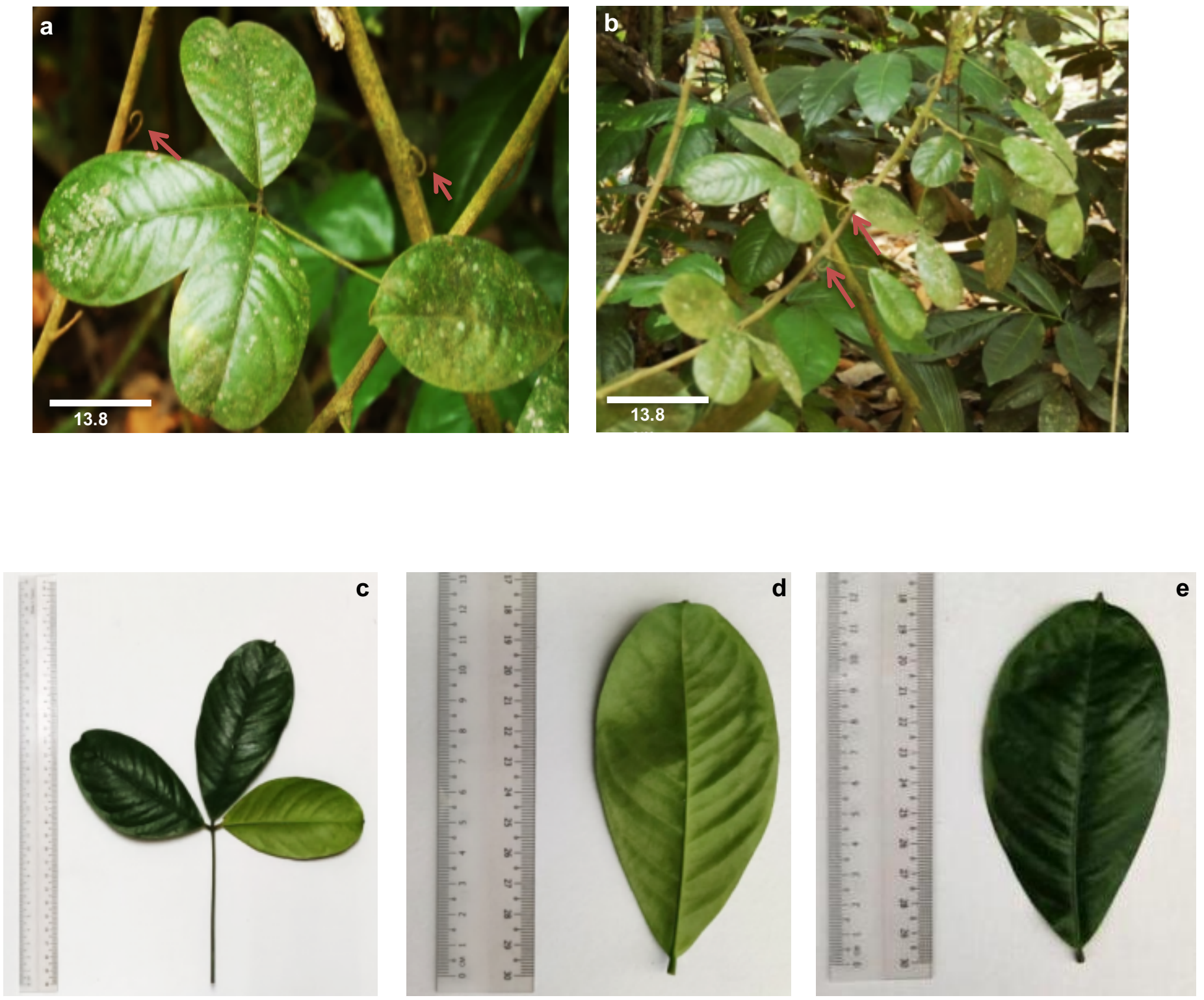

Figure 1. L. crassifolia leaf and leaflets.(a) Trifoliate leaves attached to the twigs with hooks (arrows), (b) Alternate leaf arrangements (arrows), (c) Trifoliate leaf, (d) Abaxial surface of the leaflet and (e) Adaxial surface of the leaflet. 


\section{Leaf anatomy}

The leaves of $L$. crassifolia are amphistomatic, where stomata were found on both adaxial and abaxial surfaces. On both surfaces, stomata were found to be scattered. The number of stomata observed on the abaxial surface was greater as compared to the adaxial surface. Stomata on the abaxial surface appeared in paracytic shape (Figure 2a \& 2b), whereas the stomata on the adaxial surface were identified as anomocytic (Figure $2 c \& 2 d$ ). The anomocytic stomata are sunken and embedded in the epidermal cell on the adaxial surface. The epidermal cells are in irregular polygonal shape and have a sinuous wavy anticlinal wall on both surfaces. Stomatal density and stomatal index on abaxial surfaces were significantly higher than on adaxial surfaces (Table 1). External oil glands, known as the pellucid dots, were detected on both adaxial (Figure 2e) and abaxial surfaces (Figure 2f).
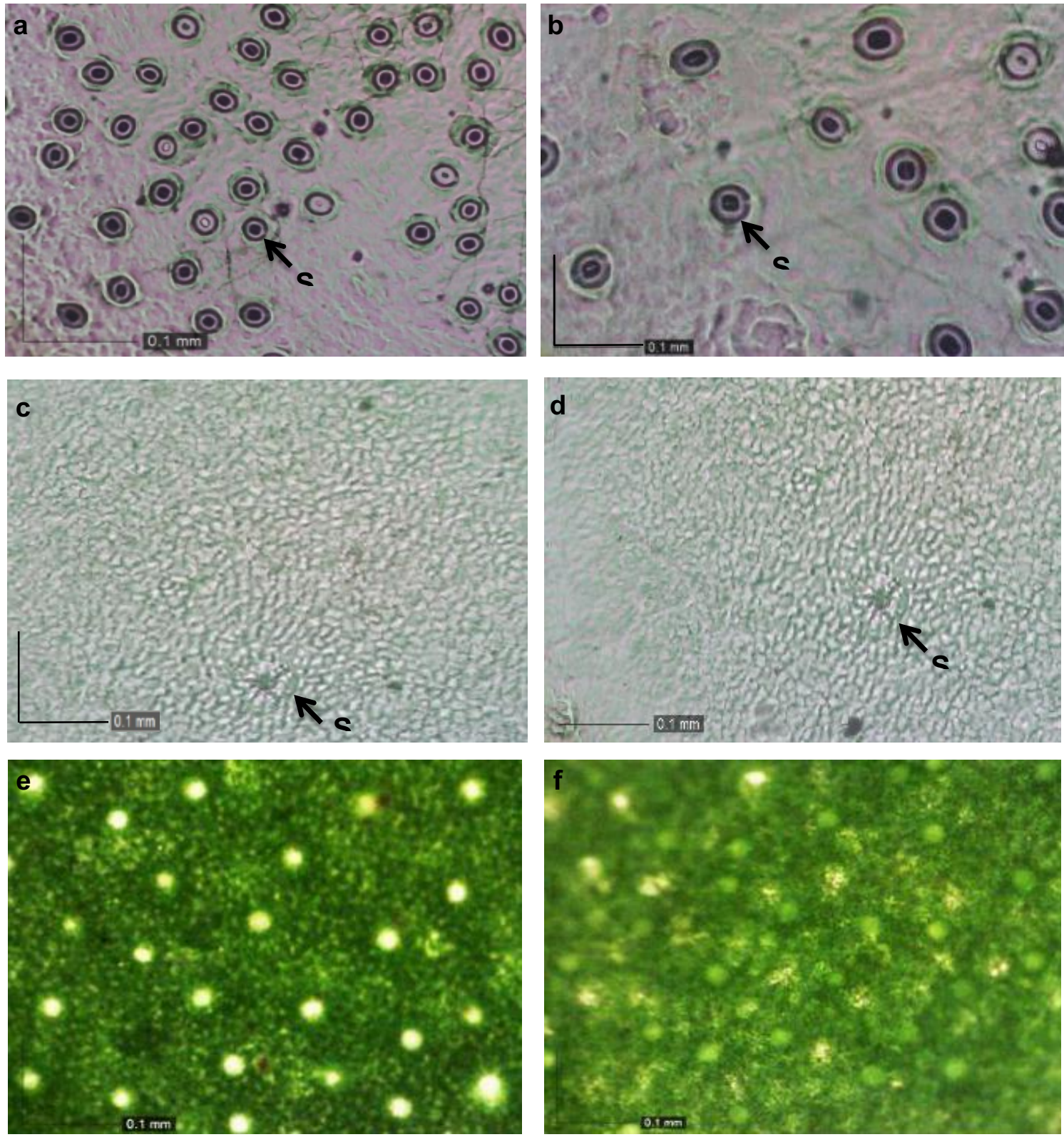

Figure 2. Stomata and pellucid dots on the adaxial and abaxial surfaces of $L$. crassifolia leaf. Stomata on the abaxial surface (a and $b)$ and the adaxial surface ( $c$ and d). External oil glands (pellucid dots) are present on both the adaxial (e) and abaxial surfaces (f). 
Table 1. Leaf parameters of Luvunga crassifolia

\begin{tabular}{llc}
\hline \multicolumn{2}{c}{ Parameters } & Values ${ }^{*} \pm$ SEM \\
\hline Stomatal density & Abaxial & $9.06 \pm 0.69^{\mathrm{a}}$ \\
& Adaxial & $1.97 \pm 0.11^{\mathrm{b}}$ \\
\multirow{2}{*}{ Stomatal index } & Abaxial & $11.18 \pm 0.82^{\mathrm{a}}$ \\
& Adaxial & $2.27 \pm 0.15^{\mathrm{b}}$ \\
\hline
\end{tabular}

* Values expressed as mean of four readings; SEM Standard Error Mean

${ }^{a b}$ Values marked with different letters are significantly different among two surfaces (abaxial \& adaxial) at $p<0.05$

Microscopic features of $L$. crassifolia leaves are shown in Figure 3. The cellular components present in the leaf blade and midrib region were observed via the transverse leaf section (Figure 3a). The leaves of $L$. crassifolia are dorsiventral with distinct adaxial and abaxial surfaces. The transverse section of the leaf lamina showed adaxial epidermis, mesophyll cells, vascular bundles, and abaxial epidermis. Appendages or trichomes were not detected along the midrib and leaf blade. Secretory cavities were abundantly present along the midrib and leaf blade (Figure 3a). Vascular bundles were also present on leaf blades and in the midrib region (Figure 3a). The transverse section of the leaf midrib was made up of an adaxial epidermis, vascular bundle, cortex, and abaxial epidermis. The adaxial surface was in plano-convex shape, whereas the abaxial surface was semicircular (Figure 3a). The epidermal cells were uni-layered and externally covered with a thin layer of cuticle. The cortical region of the midrib is comprised of parenchyma cells (Figure $3 b$ ). The vascular system in the midrib was in a closed cylindrical shape and made up of several xylem elements arranged in radial rows. Phloem was located around the xylem and towards the epidermis. An incomplete ring of pericyclic fibers was also observed towards the abaxial epidermis. On the leaf blade, the mesophyll region was distinctly differentiated by palisade mesophyll and spongy mesophyll cells. Below the adaxial epidermis, a single row of compactly arranged palisade parenchyma cells was observed (Figure 3c). In some regions of the leaf blade, the palisade parenchyma appeared multi-layered. The palisade parenchyma was in regular shape, closely packed and vertically elongated. Spongy mesophyll cells were scattered beneath the palisade parenchyma and appeared round to somewhat rectangular shaped. They were loosely arranged in eight to nine layers with large intercellular spaces. There was no sclerenchymatous idioblast detected between the mesophyll cells (Figure 3c). The adaxial and abaxial epidermal layers were uniseriate, which were made up of rectangular/barrel-shaped cells. Both abaxial and adaxial surfaces were protected by thick cuticle layers (Figure 3c), which were lignified. In the lower epidermis, a thick cuticle covered the guard cells and subsidiary cells of stomata (Figure $3 \mathrm{~d}$ ). The abaxial epidermis was abundant in stomata that were present at the same layer as the epidermal cells (Figure 3d). Bulged guard cells were observed in the stomatal aperture in the lower epidermis, and they appeared as horn-shaped ledges (Figure $3 e$ ). The presence of calcium oxalate crystals was primarily detected in the midrib region (Figure 3f). Secretory cavities observed were mostly schizogenous and were located below the adaxial and above the abaxial epidermis (Figure $3 g$ \& $3 \mathrm{~h}$ ). The double staining method used in this study distinguished between lignified and non-lignified tissues [16]. Lignified xylem tissues in the midrib were stained red by Basic Fuchsin, whereas non-lignified tissues were stained blue by Astra Blue.

\section{Stem anatomy}

Figure 4 shows the cross-section of the L. crassifolia stem. The outline of the stem sections is circular. Both the matured and young stems have a uni-layered epidermis coated with a thick layer of the cuticle (Figure 4b \& 4f). Their epidermal cells are small and rectangle-shaped. The presence of non-glandular trichomes were also detected around the surfaces of young and matured stem sections. The number of trichomes in young stem sections was more abundant than in matured stem sections (Figure $4 \mathrm{c} \& 4 \mathrm{~h}$ ). The cortex ground tissue was multi-layered and differentiated into a combination of parenchyma and collenchyma cells. Nine to fifteen layers of cells can be seen in the cortical region of the young and matured stem (Figure $4 a \& 4 f)$. Numerous secretory cavities of different sizes were found along the cortex just below the epidermis (Figure 4a \& 4f). Most of the secretory cavities observed in the young and matured stem appeared schizolysigenous (Figure $4 c \& 4 i)$. The central zone of the stems was made up of parenchymatous pith in both young and matured stem (Figure $4 a \& 4 f)$. Calcium oxalate crystals were present in the cortical region and central region of the stems (Figure $4 \mathrm{~d} \& 4 \mathrm{e}$ ). In matured stem sections, isolated patches of pericyclic fibers were arranged in circular along the inner side between cortex and phloem. Fibres were made up of 1-3 layers of cells, which were stained red by Basic Fuschin stain (Figure 4a \& 4b). Pericyclic fibers were not very well developed in young stem sections (Figure 4F $\& 4 G)$. Fibers were formed by a few sclerenchymatous cells. Below the pericyclic fibers, phloem was 
arranged in 6-8 layers in matured stem sections (Figure 4b) and 4-5 layers in young stem sections (Figure 4h). Cambium was more distinct in young stem sections compared to matured stem sections and formed between xylem and phloem (Figure $4 \mathrm{~b} \& 4 \mathrm{~g}$ ). Xylem consists of vessel elements and tracheids that were made up of sclerenchymatous cells. Xylem forms continuous cylinder with xylem rays (Figure $4 \mathrm{~b} \& 4 \mathrm{~g}$ ). The xylem was still developing in young stem sections and appeared less dense than in matured stem (Figure $4 \mathrm{f} \mathrm{\&} 4 \mathrm{~g}$ ). Stomata were also present at the same level of the epidermal layer in the young stem section (Figure $4 \mathrm{i}$ ).
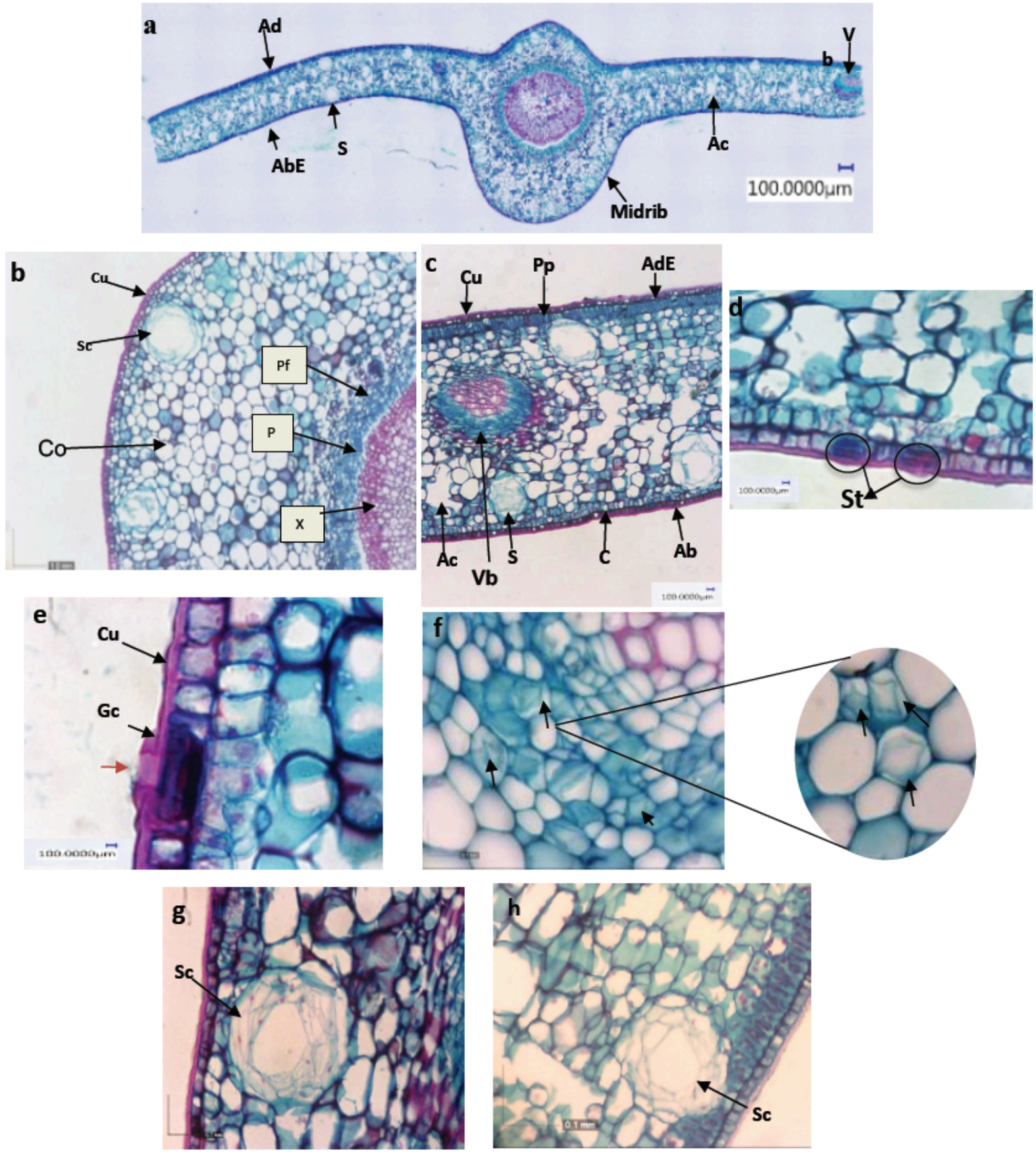

Figure 3. Microscopic features of L. crassifolia leaves. (a) Leaf transverse section, (b) Cross-section of midrib, (c) Cross-section of lamina, (d) Stomata on the abaxial epidermis, (e) Stoma with cuteculae ledges show stomatal opening (arrow), (f) Calcium oxalate crystals (arrows), (g) \& (h) Schizogenous secretory cavity. Adaxial epidermis (AdE), Abaxial epidermis (AbE), Cuticle (Cu), Vascular bundles (Vb), Air chambers (Ac), Secretory cavities (Sc), Xylem (Xy), Phloem (Ph), Pericyclic fibre (Pf), Cortex (Co), Cuticle (Cu), Palisade parenchyma (Pp), Stomata (St), Guard cells (Gc). 

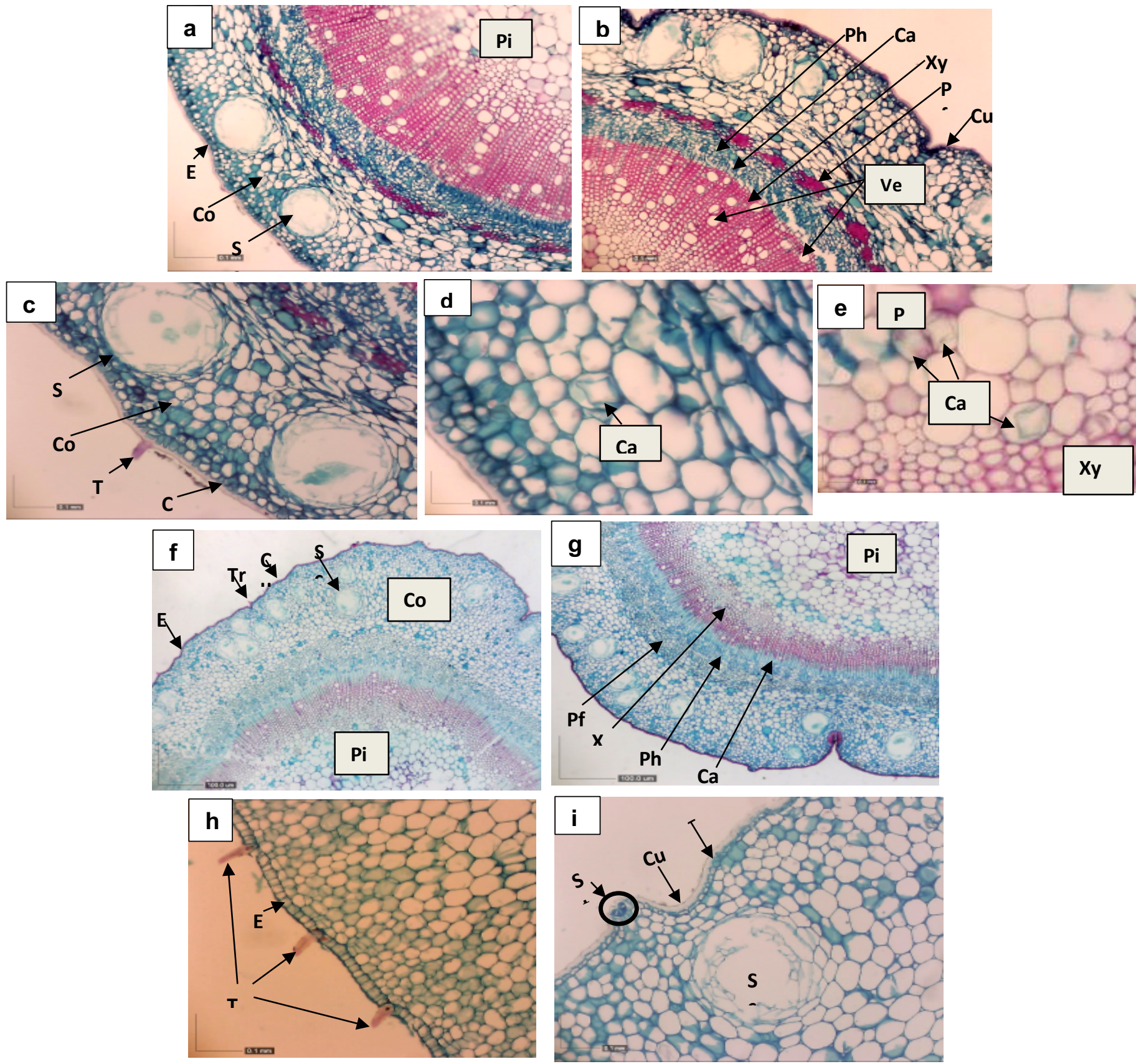

Figure 4. Cross-sections of $L$. crassifolia stem. (a-e) Matured stem transverse section of $L$. crassifolia (f-i) Young stem transverse section of L. crassifolia Epidermal (E), Xylem (Xy), Vessel elements (Ve), Phloem (Ph), Pericyclic fibre (Pf), Cortex (Co), Cambium (Ca), Pith (Pi), Trichome (Tr), Secretory cavities (Sc), Stomata (St), Calcium oxalate crystals (Cao).

\section{Petiole anatomy}

Figure 5 shows the petiole transverse section, which is circular. The petiole is composed of a single layer of rectangular-shaped cells that form the epidermis. The surface was thinly cuticularized (Figure 5a). Non-glandular trichomes detected on the surface of the petiole mostly appeared like a recurved spine and were comparatively longer than the trichomes on the stem sections. The cortical region consists of 9-11 layers of parenchyma cells (Figure $5 b$ ). Schizolysigenous secretory cavities were present along the cortical region (Figure $5 \mathrm{c}$ ). The vascular bundle was arranged in a circular form and was made up of a few layers of primary xylem and phloem. Pericyclic fibers were developing on the outer layer of the phloem (Figure $5 b \& 5 c$ ). The central region of the petiole was made up of layers of parenchymatic cells. 

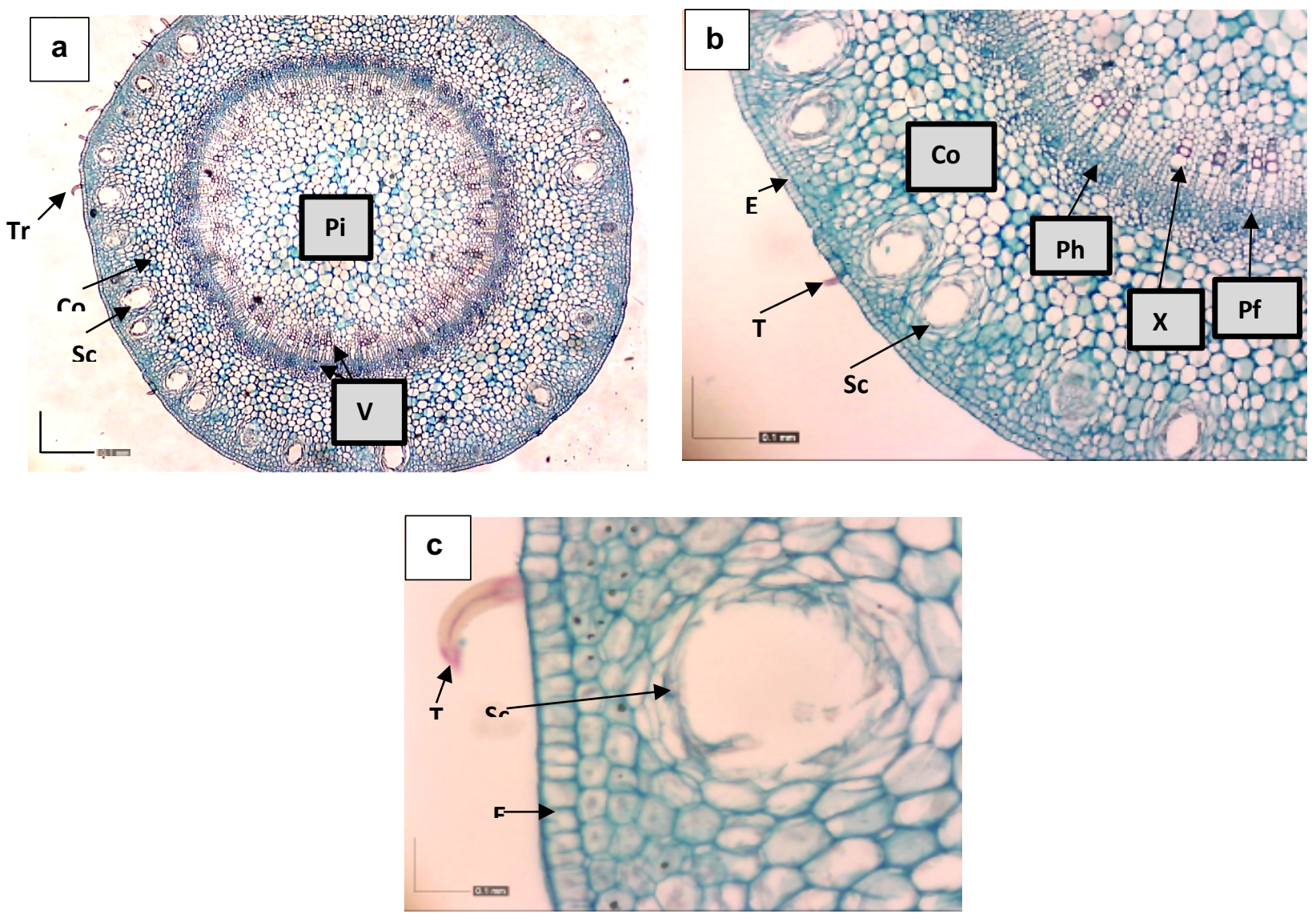

Figure 5. Cross-sections of L. crassifolia petiole. (a-c): Petiole stem transverse section. Epidermal (E), Xylem (Xy), Phloem (Ph), Pericyclic fibre (Pf), Cortex (Co), Pith (Pi), Trichome (Tr), Vascular bundle (Vb), Secretory cavities (Sc)

\section{Discussion}

Morphological and anatomical analyses on different types of tissues are necessary for the identification and taxonomic evaluation of a plant. For example, leaf epidermal analyses provide significant values to determine phylogeny and taxonomy of closely related species [17]. These analyses are also crucial for the initial identification of plant materials and drug evaluation in pharmacognosy [18]. This is the first report that highlights the macroscopic and microscopic features of the leaf, stem, and petiole of the $L$. crassifolia plant from the Rutaceae family. In this study, morphological characteristics such as leaf arrangement, leaf attachment, leaf margin, leaf base, leaf apex, and venation of leaves serve as a parameter for future references and correct authentication of this plant. Based on this study, morphological characterization showed that $L$. crassifolia have compound trifoliate leaves and are alternately attached to the stems. The leaflets are also unlobed and have smooth margins. Similar characteristics were also exhibited by Poncirus trifoliate from the Rutaceae family, which has trifoliate compound leaves in alternate arrangements. In addition, spines or stouts can be seen attached to the twigs and branches [19]. In another species in Luvunga, i.e., L. sarmentosa possesses spines attached to its stem for climbing by twinning mechanism [20]. Besides that, L. monophylla, also a climber, has short recurved spines up to $5 \mathrm{~mm}$ long, found in leaf axil and larger spines on older twigs [21]. Other than that, L. crassifolia was observed to have spike-like hooks on twigs and stems, which aids in climbing. A study by Mabberley [22] stated Paramignya sp. possibly fall under the same genus as Luvunga sp. within the Rutaceae family due to the similarities in general appearances.

Stomatal types and stomatal arrangement of a plant can best illustrate plant taxonomy and its phylogenetic hierarchy, which can be a piece of basic phylogenetic information [23]. L. crassifolia leaves 
have stomata on both surfaces (amphistomatic) but significantly more on their abaxial side. The stomatal arrangement was found to be paracytic on the abaxial surface and anomocytic on the adaxial surface. A paracytic stoma is surrounded by a single distinct or indistinct subsidiary cell. An anomocytic stoma is surrounded by four or more subsidiaries, variable in position, shape, and size [24]. There is no established study on stomatal types and arrangements for $L$. crassifolia or any other plant species of the same genus. In this study, stomatal density and stomatal index exhibited a significant difference, in which a larger number of stomata were identified on the abaxial surface than on the adaxial surface. This characteristic could be an adaptive feature of this species to deal with environmental changes and abiotic factors [25]. Stomatal parameters such as stomatal density and stomatal index are crucial in evaluating leaf origin crude drugs as they can serve as a tool to assess the authenticity and purity of drugs [26]. These parameters, including stomatal size and stomatal pore size, can also be helpful to differentiate the taxa at specific and inter-specific levels [27]. Stomatal density and stomatal index were also determined in this study and statistically analyzed. Thus, these can be vital information for pharmacognostic evaluation for upcoming studies of $L$. crassifolia.

The most prominent feature of plants species in the Rutaceae family is schizogenous secretory cavities [28]. Specialized secretory structures such as glandular trichomes, secretory cavities, and secretory ducts are known for the production and development of plant gums, resins, and essential oil in large quantities. There are three possible ways in which these cavities and ducts are formed, which are lysigeny, schizogeny, and schizolysigeny. Lysigeny is a process that involves the autolysis of a mass of mature secretion-filled glandular cells that release the secretion product as they degenerate. Schizogeny involves the separation of cell walls in the centre of a group of glandular cells, creating an intercellular space that enlarges greatly during development. Schizolysigeny combines the two processes where cavities initiate schizogenous-ly but further increase in size due to autolysis of glandular cells [29]. Based on the work done by Turner et al. [30], it was stated that lysigenous secretory glands are formed as a result of artifactual preparations of the gland tissues because epithelial cells of the glands in Citrus remain intact long after the initial secretory phase. The present study on the anatomy of $L$. crassifolia showed the abundance of schizogenous secretory cavities on the leaf sections and schizolysigenous secretory cavities on the stem and petiole sections, which could be the potential storage sites for essential oils of this plant species. Soundappan et al. [31] revealed that schizolysigenous secretory cavities were observed on the stem sections of Murraya Koenigii (Rutaceae). The shoot apex of Metrodorea nigra A. St.-Hil from the Rutaceae family was also reported to possess a similar pattern of secretory cavities [32]. Apart from that, the stem and leaf sections of the Haplophyllum telephioides (Rutaceae) contained schizogenous glands [33]. On the leaves of the Rutaceae plants, secretory cavities or glands containing oil appear as translucent pellucid dots [28]. These pellucid dots were observed on both adaxial and abaxial surfaces of $L$. crassifolia leaves. The translucent pellucid dots resemble glandular cavities that produce aromatic essential oil and are visible when the leaf is held up to the light. Pellucid dots are also one of the characteristic features of species' from the Rutaceae family [34].

Trichomes are generally simple or compound [28] in plant species of the Rutaceae family, such as Poncirus trifoliata, Citrus $x$ paridisi and Murraya paniculata [35]. In L. crassifolia, the presence of trichomes was not detected on the leaf sections but present on the young and matured stems and also petiole sections of $L$. crassifolia. The trichomes observed in this study are similar to the report of Sedeek [36], who studied the macro-morphological and micro-morphological features of Citrus maxima (Burm.) Merrill, another member of the Rutaceae family, shows the presence of trichomes on stem surfaces. Not only that, Jarald [37] studied the morphoanatomy of Murraya koenigii stem (Rutaceae) and also detected the presence of trichomes on the surface of young stems. Trichomes are categorized as glandular and non-glandular. Glandular ones could be peltate or capitate, depending on their shape and structure. Esenbeckia leiocarpa and Helietta apiculate, two species of the Rutaceae family, have capitate trichomes and peltate trichomes, respectively [38]. Trichomes on L. crassifolia stems and petiole are non-glandular. The density of trichomes on young $L$. crassifolia stems was more prominent than in matured stems. The abundance of trichomes in young stems of the species could be associated with the defence mechanism against biotic and abiotic stresses to protect the young and vulnerable tissues [35].

\section{Conclusions}

Overall, macroscopic and microscopic analyses on $L$. crassifolia can provide key information in basic identification and phylogenetic studies as this is the first report on leaf morphology and anatomy of leaves, stems and petioles. Findings from this study summarize that the leaf of $L$. crassifolia is trifoliate and amphistomatic. It has notable characteristics of Rutaceae, such as external oil glands and schizogenous secretory cavities. Meanwhile, the stem and petiole sections have schizolysigenous secretory cavities and non-glandular trichomes. Leaf epidermal studies and identification of various tissues can be set as fingerprints for proper identification of plants for future pharmacology studies. 
Morphology and anatomy of leaves, stems and petiole are also valuable diagnostic features for characterization, standardization and identification of specific species.

\section{Conflict of interest}

The authors declare that there is no conflict of interest regarding the publication of this paper.

\section{Acknowledgment}

This project was financially supported by the UPM High Impact Putra Grant [GPB/2017/9559900]. Ms Sugathini is supported by the Graduate Research Fellowship (GRF) from UPM.

\section{References}

[1] D. J. Mabberley, "Mabberley's plant-book: A portable dictionary of plants, their classifications and uses," $3^{\text {rd }}$ Edition, Cambridge University Press, 2008.

[2] Y. Roskov , T. Kunze , T. Orrell et al., "Species 2000 \& ITIS Catalogue of Life, 2014 Annual Checklist," www.catalogueoflife.org/annual-checklist/2014, Species 2000: Naturalis, Leiden, the Netherlands, 2014. (Accessed: 18 February 2020)

[3] M. Groppo, J. R. Pirani, M. L. Salatino, S. R. Blanco, and J. A. Kallunki, "Phylogeny of Rutaceae based on twononcoding regions from cpDNA," American Journal of Botany, vol. 95, no. 8, pp. 985-1005, 2008.

[4] N. T. Son, "Notes on the genus Paramignya: Phytochemistry and Biological activity," Bulletin of Faculty of Pharmacy, Cairo University, vol. 56, no. 1, pp. 1-10, 2018.

[5] N. G. Dengler, "An integral part of botany," American Journal of Botany, vol. 89, no. 2, pp. 369-373, 2002.

[6] K. A. Babalola,, \& A. A. Victoria, "Foliar Epidermal Morphology of Two West African Genera of Haloragaceae R. BR.(Saxifragales)," Journal of Scientific Research and Development, vol. 11, pp. 84-91, 2009.

[7] Tanaka, Meded, Rijks-Herb, 69:8,1931.

[8] W. T. Swingle, \& P. C. Reece, "The botany of Citrus and orange relatives in the orange subfamily," The Citrus Industry, vol. 1, pp. 190-340, 1967.

[9] R. R. Krueger, and L. Navarro, "Citrus germplasm resources," Citrus genetics, breeding and biotechnology, vol. 45, pp. 140, 2007.

[10] A. Latiff, I. Faridah Hanum, A. Zainudin Ibrahim et al., "On the vegetation and flora of Pulau Tioman, Peninsular Malaysia," Raffles Bulletin of Zoology, vol. 47, pp. 11-72, 1999.

[11] D. J. Mabberley, "Australian Citreae with notes on other Aurantioideae (Rutaceae)," Telopea, vol. 7, no. 4, pp. 333-344, 1998.

[12] A. Ash, "Manual of leaf architecture: morphological description and categorization of dicotyledonous and netveined monocotyledonous angiosperms," Smithsonian Institution, 1999.

[13] B. W. Grant, and I. Vatnick, "Environmental correlates of leaf stomata density," Teaching issues and Experiments in Ecology, vol. 1, no. 1, pp. 1-24, 2004.

[14] K. Khandelwal, "Practical pharmacognosy techniques and experiments," $19^{\text {th }}$ edition, Mumbai, Pragati Books Pvt. Ltd., 2008.

[15] D. A. Johansen, "Plant microtechnique," Plant microtechnique, 1940.

[16] J. E. Kraus, H. C. de Sousa, M. H. Rezende et al., "Astra blue and basic fuchsin double staining of plant materials," Biotechnic \& histochemistry, vol. 73, no. 5, pp. 235-243, 1998.

[17] M. I. Barkatullah, G. Jelani, and I. Ahmad, "Leaf, stem bark and fruit anatomy of Zanthoxylum Armatum dc.(Rutaceae)," Pakistan Journal of Botany, vol. 46, no. 4, pp. 1343-1349, 2014.

[18] S. Singh, L. Manchawal, and M. G. Chauhan, "Pharmacognostic study of male leaves of Trichosanthes dioica Roxb. with special emphasis on microscopic technique," Journal of Pharmacognosy and Phytotherapy, vol. 2, no. 5 , pp. 71-75, 2010.

[19] G. L. Nesom, "Citrus trifoliata (Rutaceae): Review of biology and distribution in the USA," Phytoneuron, vol. 46, pp. 1-14, 2014.

[20] A. Padaki, and N. Parthasarathy, "Abundance and distribution of lianas in tropical lowland evergreen forest of Agumbe, Central Western Ghats, India," Tropical Ecology, vol. 41, no. 2, pp. 143-154, 2000.

[21] Luvunga monophylla (DC.) Mabb, Australian Tropical Rainforest Plants, $8^{\text {th }}$ Edition, CSIRO Publication, https://apps.lucidcentral.org/rainforest/text/entities/luvunga_monophylla.htm, 2020, (Accessed: 23 April 2020).

[22] D. J. Mabberley, "Citrus (Rutaceae): A review of recent advances in etymology, systematics and medical applications," Blumea-Biodiversity, Evolution and Biogeography of Plants, vol. 49, no. 2-3, pp. 481-498, 
2004.

[23] I. Hameed, F. Hussain, and G. Dastagir, "Stomatal studies of some selected medicinal plants of Polygonaceae," Pakistan Journal of Botany, vol. 40, no. 6, pp. 2273-2280, 2008.

[24] M. Prabhakar, "Structure, delimitation, nomenclature and classification of stomata," Acta Botanica SinicaEnglish Edition, vol. 46, no. 2, pp. 242-252, 2004.

[25] N. A. Igboabuchi, and C. V. Ilodibia, "A Study on the Anatomy of Zanthoxylum macrophylla (L.) Sarg.(Rutaceae)," Asian Journal of Biology, pp. 1-6, 2017.

[26] D. Kumar, K. Kumar, S. Kumar et al., "Pharmacognostic evaluation of leaf and root bark of Holoptelea integrifolia Roxb, "Asian Pacific journal of tropical biomedicine, vol. 2, no. 3, pp. 169-175, 2012.

[27] S. Nabin, S. C. Nath, and D. Simanta, "Foliar micromorphological characters of few taxa of the genus Aquilaria Lamk growing in North-East India," Advances in Plant Sciences, vol. 13, no. 2, pp. 551-558, 2000.

[28] K. Kubitzki, J. A. Kallunki, M. Duretto, and P. G. Wilson, "Rutaceae," In Flowering Plants. Eudicots, The Families and Genera of Vascular Plants, Springer, Berlin, Heidelberg, vol. 10, pp. 276-356, 2010.

[29] G. W. Turner, "A brief history of the lysigenous gland hypothesis," The Botanical Review, vol. 65, no. 1, pp. 76-88, 1999.

[30] G. W. Turner, A. M. Berry, and E. M. Gifford, "Schizogenous secretory cavities of Citrus limon (L.) Burm. F. and a reevaluation of the lysigenous gland concept," International Journal of Plant Sciences, vol. 159, no. 1, pp. 75-88, 1998.

[31] K. Soundappan, R. Bajaj, B. N. Vaidya, and N. Joshee, "Anatomical and biochemical investigations on medicinal tree Murraya koenigii Spreng," Journal of Biotech Research, vol. 9, pp. 70-78, 2018.

[32] S. R. Machado, Y. Canaveze, and T. M.Rodrigues, "Structure and functioning of oil cavities in the shoot apex of Metrodorea nigra A. St.-Hil.(Rutaceae)," Protoplasma, vol. 254, no. 4, pp. 1661-1674, 2017.

[33] M. Tekin and N. Eruygur, "The structural studies on the medicinal plant Haplophyllum telephioides," Revista Brasileira de Farmacognosia, vol. 26, no. 5, pp. 544-552, 2016.

[34] R. Charoensup, T. Duangyod, P. Phuneerub, and C. Singharachai, "Pharmacognostic specification of Zanthoxylum limonella (Dennst.) Alston: Fruits and seeds in Thailand," Journal of Advanced Pharmaceutical Technology \& Research, vol. 7, no. 4, pp. 134, 2016.

[35] D. G. Hall, E. D. Ammar, and K. D. Bowman, "Epifluorescence and stereomicroscopy of trichomes associated with resistant and susceptible host plant genotypes of the Asian citrus psyllid (Hemiptera: Liviidae), vector of citrus greening disease bacterium," Journal of Microscopy and Ultrastructure, vol. 6, no. 1, pp. 56, 2018.

[36] M. S. Sedeek, N. F. Kirollos, C. G. Michel, and M. A. Abdel-Kawy, "Botanical and genetic characterization of Citrus maxima (BURM.) Merrill. F. Rutaceae," International Journal of Pharmacy and Pharmaceutical Sciences, vol. 9, no. 1, pp. 260-272, 2017.

[37] E. E. Jarald, E. Sheeja, S. Parial, H. Arya, and A. Bajpai, "Morphoanatomy of stems of Murraya koenigii Spreng," Journal of Biological Sciences, vol. 8, no. 3, pp. 654-658, 2008.

[38] T. G. Muntoreanu, R. da Silva Cruz, and G. F. Melo-de-Pinna, "Comparative leaf anatomy and morphology of some neotropical Rutaceae: Pilocarpus Vahl and related genera," Plant Systematics and Evolution, vol. 296, no. 1-2, pp. 87-99, 2011. 